\title{
A Preliminary Study of Tobacco Mosaic Virus by the Gel Diffusion Precipitin Tests
}

\author{
BY A. KLECZKOWSKI \\ Rothamsted Experimental Station, Harpenden, Hertfordshire
}

\begin{abstract}
SUMMARY : A number of proteins can be separated from purified preparations of tobacco mosaic virus; they differ from each other antigenically and all differ from the intact virus by not possessing all antigenic determinant groups possessed by the virus. Some of these proteins are easily detached from the virus by such mild treatments as placing it in a protein solution or in agar gel. These are antigenically identical with the ' $X$-protein' which remains in the supernatant fluid when the virus is sedimented by ultracentrifugation from sap of infected plants. More of these proteins are detached from the virus by placing it in borate buffer at $c$. $\mathrm{pH} 8.7$. When a more drastic treatment is applied, such as incubation at $c . \mathrm{pH} \mathrm{10,} \mathrm{which} \mathrm{disintegrates} \mathrm{a} \mathrm{proportion} \mathrm{of}$ the virus, still more of these proteins are released, but then some proteins antigenically different from those of ' $\boldsymbol{X}$-protein' are also released.
\end{abstract}

Different variants of the gel diffusion precipitin test have been applied to preparations of tobacco mosaic virus (TMV) by Sang \& Sobey (1954), van Slogteren (1955), Jeener, Lemoine \& Lavand' Homme (1954) and Commoner \& Rodenberg (1955). All except Commoner \& Rodenberg found two or three antigenically different components, and Jeener et al. gave evidence that the major component is identical with the virus and the others with the non-infective protein which appears in the plant as a result of infection with TMV and remains in the supernatant fluid when the virus is sedimented from fresh plant extracts by ultracentrifugation. This protein will be called $X$-protein, although the name was originally given by Takahashi \& Ishii $(1952,1953)$ to a component with a rate of electrophoretic mobility slightly smaller than half that of the virus, and subsequently more components with different mobilities were found (Commoner, Yamada, Rodenberg, Wang \& Basler, 1953; Jeener et al. 1954). $X$-protein is precipitated by antisera made against normal preparations of TMV. Some workers found that the antisera absorbed by $X$-protein still precipitate TMV (Jeener et al. 1954; Starlinger, 1955) and other workers that they do not (Bawden \& Pirie, 1956).

The minor components could be distinguished in the gel diffusion tests from the major component because they diffused through agar much faster than did the major component and thus had relatively small particles. Preparations of TMV, homogeneous in the gel diffusion test, should, therefore, be obtained if they are prepared by ultracentrifugation, or, if prepared by other methods, should be made homogeneous by ultracentrifugation. Preliminary experiments showed, however, that these expectations were not realized and that purified preparations of TMV normally contain serologically distinguishable components which are not separable by ultracentrifugation. Experiments were, therefore, made to gain some information about their origin and relationship 
to $X$-proteir and also to the similar protein that can be split from purified preparations of 'TMV by incubation at $\mathrm{pH} 9 \cdot 5-10 \cdot 5$ (Schramm, 1943). This protein was called $\boldsymbol{A}$-protein by Schramm, Schumacher \& Zillig (1955) and considered to be identical with $X$-protein by Schramm \& Zillig (1955) and by Starlinger (1955) who found that antiserum to TMV absorbed with $A$ protein did not precipitate $X$-protein, although it still precipitated TMV. Schramm \& Zillig (1955) obtained electrophoretically homogeneous preparations of $X$ protein with the same rate of mobility as $A$-protein (slightly smaller than half the rate of TMV), and suggested that the various components with different mobilities observed by other workers resulted from differences in the degree and type of aggregation of one basic material. The results of the present work show that $X$ - and $A$-proteins differ antigenically from intact typical virus, but are not identical, and each is antigenically heterogeneous.

\section{METHODS}

Antisera were prepared by intravenous injection into rabbits of virus preparations purified without the use of an ultracentrifuge. Usually about $10 \mathrm{mg}$. virus were injected intravenously into rabbits six times at weekly intervals and the animals bled about 10 days after the last injection. Sometimes the animals were kept after such a series of injections for several months, given a second series of two or three injections and then bled.

Tobacco mosaic virus (TMV) was purified, usually from sap of systemically infected tobacco plants, by repeated alternate precipitation by one-third saturation with $\left(\mathrm{NH}_{4}\right)_{2} \mathrm{SO}_{4}$ and by adjusting the $\mathrm{pH}$ value to $3 \cdot 4$. The procedure was continued as long as it was obvious that contaminating material was being removed with the supernatant fluid when precipitated virus was sedimented by centrifugation $(c .10,000 \mathrm{rev} . / \mathrm{min}$.), or centrifuged down after the virus had been dissolved. Tomato bushy stunt virus (BSV) was purified from sap of infected tomato plants by several successive precipitations by onethird saturation with $\left(\mathrm{NH}_{4}\right)_{2} \mathrm{SO}_{4}$, removal of some contaminating material that became insoluble at $\mathrm{pH} 3 \cdot 4$, and crystallizing the virus by adding enough $\left(\mathrm{NH}_{4}\right)_{2} \mathrm{SO}_{4}$ to produce faint opalescence at room temperature and then keeping the preparation for a few weeks at $2^{\circ}$. The purified preparations of both viruses were finally dialysed against distilled water and stored at $\mathbf{2}^{\circ}$. Usually after dialysis it was possible to remove more contaminating material by centrifugation. The final preparations of the viruses were almost colourless at $c .4 \%$ $(\mathrm{w} / \mathrm{v})$ concentrations.

Two variants of the gel diffusion precipitin test were used; one was done in test tubes of $1 \cdot 1 \mathrm{~cm}$. diameter (the 'tube method'), and the other in Petri dishes of 9-10 cm. diameter (the 'Petri dish method'). In both $0.5 \%(\mathrm{w} / \mathrm{v})$ agar in $0.9 \%(\mathrm{w} / \mathrm{v}) \mathrm{NaCl}$ solution (with addition of sodium azide in the proportion of $1 / 5000$ ) was used.

The tube method was a modification of that originally used by Oakley \& Fulthorpe (1953): $1 \mathrm{ml}$. of antiserum diluted in agar was poured first into the tube; when this had solidified $1 \mathrm{ml}$. of agar alone was poured in and when this 
had solidified $1 \mathrm{ml}$. of antigen diluted in agar was poured in. The Petri dish method was a modification of the original method of Ouchterlony (1949). Twenty ml. agar were poured into a Petri dish. Holes, usually rectangular, were made in the agar either by placing pieces of metal in the dish before pouring agar and removing them after the agar solidified, or by removing pieces of solidified agar with a scalpel and spatula. The holes were filled with antisera and with antigens, both diluted in agar. The dilution factor was never greater than $1 / 10$, so that the antiserum and antigen solutions in agar solidified to about the same degree of firmness as did the surrounding agar. (For diluting antisera and antigens the agar was melted and cooled to $42^{\circ}$.)

Diffusion of antigens and antibodies from their original positions through the intervening agar towards each other results in differently directed concentration gradients and precipitates form within the agar where two conditions are fulfilled: the ratio of concentrations of antigen and antibody is such that precipitation can occur, and the total concentration of either is above some limiting value. The term 'lines' of precipitate will be used, although really the precipitate occupied disk-shaped spaces in the tubes and spaces of various shapes in the plates. The lines usually started to be visible within a few days, and then grew in intensity and thickness, sometimes moving their positions. Observation of the lines was continued for a month or longer. The terms 'layer' of antigen or antiserum (for the tube method) and 'area' of antigen or antiserum (for the Petri dish method) will be used to describe the original positions of antigens and antisera, although antigens and antibodies may have diffused and no longer have been confined to these positions.

The formation of several lines has three possible explanations. (1) There may be several different antigens and several different antibodies, and each antigen-antibody system may establish the ratio suitable for precipitation in a different position. The antigens may or may not possess common determinant groups, but must differ from each other by possession of some groups which are not possessed by the others, because only antibodies that do not correspond to any determinant group of a given antigen can pass unhampered beyond the position where that antigen has formed a precipitation line, to form a precipitation line elsewhere with another antigen. (2) Homogeneous antigen may produce something similar to the Liesegang phenomenon, resulting in a multiplicity of lines, rather close to each other (this has been discussed by Wilson \& Pringle, 1954). (3) Several lines may be formed by an antigenically homogeneous material because it exists in a number of forms differing widely from each other in physical properties (e.g. particle size, diffusion rate, solubility). This is particularly relevant to virus preparations such as those of TMV, which do contain various particles differing from each other in this way.

When two lines cross without much affecting each other's course, as they may do in agar plates when two or more antigenic preparations are tested against one or more antisera, the conclusion that the two lines are formed by two different antigens seems unavoidable. On the other hand, when two lines, formed by two materials present in two different preparations, bend towards each other and fuse to form a perfect continuation of each other, the conclusion 
is that the two materials are antigenically identical. When, however, the lines remain separate and do not cross (they are always parallel when the tube method is used), the possibilities (2) and (3) cannot be ruled out. Thus the appearance of several lines which did not cross was considered only as an indication, but not as sufficient evidence that there were as many different antigens in a tested material. Attempts were then made to find other evidence and to separate and identify the antigens.

\section{RESULTS}

\section{Multiplicity of precipitation lines obtained with preparations of $T M V$ and} $B S V$, purified without the use of ultracentrifuge

Fig. 1 shows a typical result obtained by the tube method with the preparation of TMV and the antiserum mostly used in this work. There are three lines of precipitation, one $(a)$ near the antigen layer, and the other two $(b$ and $c$ ) close to each other about half way between antigen and antiserum layers. A very similar result was obtained with a preparation of BSV and its antiserum. All the lines were specific for each virus preparation, for they were formed only with homologous antisera even when the two viruses were propagated on the same host (tomato). It is possible, therefore, that the virus preparations contained at least three different antigens, which may, or may not, possess common determinant groups.

The photograph shown in Fig. 1 was taken 6 days after the test was set up; later the lines became more intense and thicker. The increase in thickness occurred upwards (i.e. towards the antigen layer), the position of the lower edges remaining almost unaltered. Eventually the two lower lines $(b$ and $c$ ) coalesced, and the upper line $(a)$ became the most intense and the thickest and it encroached into the antigen layer.

The position of (the lower edges of) the lines depends on the ratio of initial concentrations of antigen and antiserum at their starting positions. Table 1 shows that when the concentrations of the two materials vary but the ratio is kept constant, the positions of the lines do not alter appreciably. When the ratio is altered, the lines form farther away from the initial position of the material whose concentration is increased in relation to the other material.

Table 1. The dependence of the position of precipitation lines on the ratios of initial concentrations of antigen and antiserum

The figures show approximate distances (in $\mathrm{mm}$.) between the lower edge of the line $c$ (see Fig. 1) and the interface between the antigen layer and the blank agar layer. (The height of the blank layer was about $10 \mathrm{~mm}$.)

$\begin{array}{cccc}\begin{array}{c}\text { Dilution of antiserum } \\ \text { in the bottom layer } \\ \text { of agar }\end{array} & \begin{array}{c}\text { Initial concentrations of TMV in the } \\ \text { top layer of agar } \\ 0.025 \%\end{array} & \begin{array}{c}0.006 \% \\ \text { Distance of line } c(\mathrm{~mm} .)\end{array} \\ 1 / 10 & 3 & 2 & 1 \\ 1 / 40 & 5 & 3 & 2 \\ 1 / 160 & \begin{array}{c}0.1 \% \text { visible } \\ \text { line }\end{array} & 5 & 2 \cdot 75\end{array}$


The three lines of precipitation shown in Fig. I were not obtained with all the different antisera used. All formed the line $a$ (nearest the antigen layer) and this was the only line formed by some, whereas the other antisera formed another line further away from the antigen layer, or another two lines ( $b$ and $c$ ).

Usually rabbits given only few injections of small amounts of TMV produced antisera which formed only one line $(a)$, whereas further injections of the same animals with the same TMV preparation resulted in antisera which formed, in addition to the line $a$, another line or another two lines $(b$ and $c$ ). Sang $\&$ Sobey (1954), who used another method of the gel diffusion test, also noticed that only one precipitation line was obtained with antisera produced by injecting rabbits twice with small amounts of TMV, and that a second line appeared after a more prolonged course of injections. This is the first evidence that all the three lines were not formed by an antigenically homogeneous material, for the most likely explanation of these results is that the rabbits which received small amounts of a TMV preparation, produced antibodies that reacted only with the antigen which formed the line $a$, whereas after more injections with larger amounts of antigen, antibodies were also produced which reacted with the antigen or antigens that formed the other two lines.

\section{Separation of antigens by absorption with antiserum}

If different antigens and antibodies are involved in forming different precipitation lines, it should be possible to remove some of the antigens and leave the others by precipitation with an antiserum which contains only some of the antibodies. To test this two antisera were used: antiserum I, produced by the usual series of injections and which formed the three lines shown in Fig. 1;
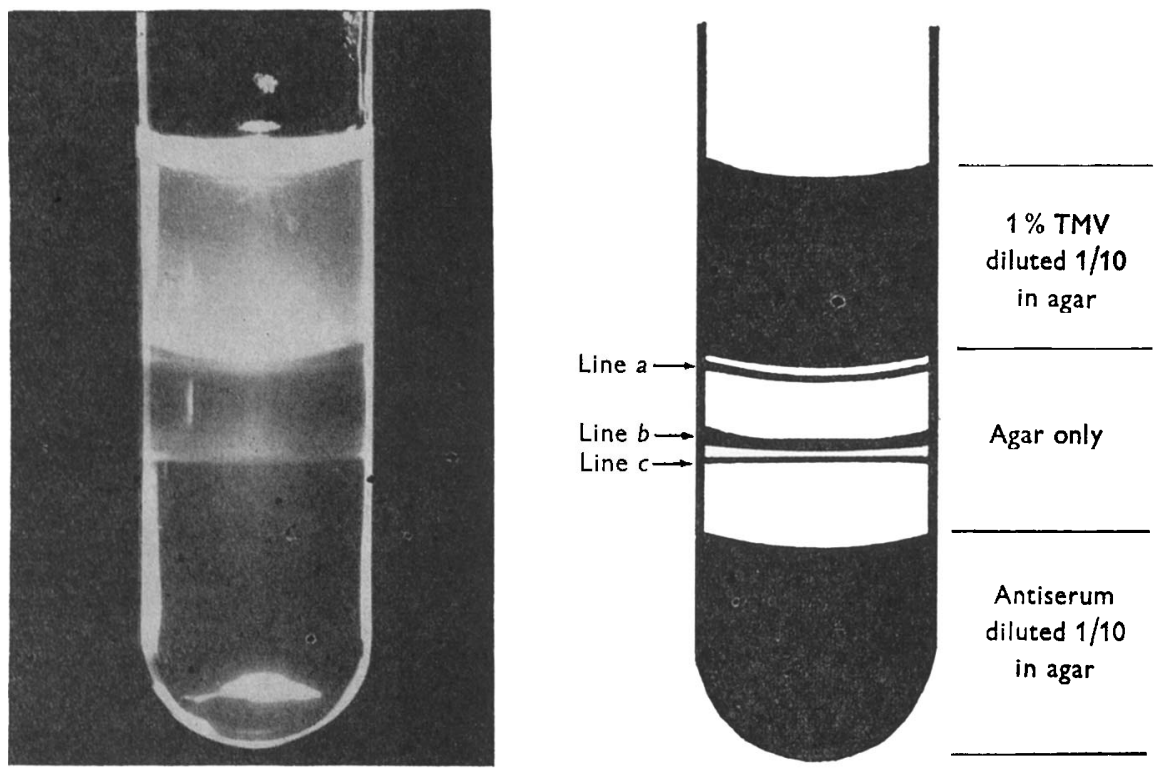

Fig. 1. Precipitation lines formed by a TMV preparation with an antiserum. 
antiserum II, produced by a single injection of $2 \mathrm{mg}$. TMV and which formed only one line $(a)$. The correspondence of the single line formed by antiserum II with the line $a$ formed by antiserum I was confirmed by the Petri dish method, when the two lines joined, forming a continuation of each other (Fig. 2).

The virus preparation was absorbed with antiserum II. The details are given in Table 2, which shows that when the ratio of the amount of the antiserum to that of the virus was as in tube no. 3, or higher, all the material that could precipitate with antiserum II was precipitated, whereas some other material that could precipitate only with antiserum I still remained in solution. Typical virus particles were precipitated by antiserum II, for nothing could be seen when the supernatant fluid from tube no. 3 after the first test (Table 2) was examined in the electron microscope, and no lesions were obtained when the fluid (undiluted, and diluted 1/10 and 1/100) was inoculated to leaves of Nicotiana glutinosa.

\section{Table 2. Absorption of a $T M V$ preparation with antiserum II}

The second test was made by adding $0 \cdot 1 \mathrm{ml}$. of antiserum II or I at a dilution of $1 / 10$ to $2 \mathrm{ml}$. of each supernatant fluid obtained by removing the precipitates formed during the first test by centrifugation for $10 \mathrm{~min}$. at $10,000 \mathrm{rev} . / \mathrm{min}$. All fluids contained $0.9 \% \mathrm{NaCl}$, and during the tests the tubes were incubated for $3 \mathrm{hr}$. at $50^{\circ}$ and then overnight at room temperature. + signs indicate the presence and the degree of precipitation; - signs indicate the absence of precipitation.

Tube no.

\begin{tabular}{|c|c|}
\hline 3 & 4 \\
\hline
\end{tabular}

First test: $3 \mathrm{ml}$. of $0 \cdot 02 \%$ solution of TMV $+3 \mathrm{ml}$. of antiserum II at a dilution of :

$\begin{array}{cccccc}1 / 10 & 1 / 20 & 1 / 40 & 1 / 80 & 1 / 160 & \text { Saline } \\ ++++ & ++++ & ++++ & ++++ & +++ & - \\ - & & \text { Second test with antiserum II } & & \\ & & - & \pm & ++ & ++++ \\ + & + & \text { Second test with antiserum I } & & \end{array}$

As it was possible that the negative results of the electron-microscopic examination and of the infectivity test were obtained because too low a concentration of the material remained in the supernatant fluid of the tube no. 3, another experiment was made in which antiserum II and the virus preparation were mixed in the same proportions but 40 times more concentrated. The precipitate was removed by centrifugation. Nothing could be found in the supernatant fluid by examination with the electron microscope. The material that remained in the supernatant fluid was then freed as much as possible from serum proteins. This was done by one-fourth saturation with $\left(\mathrm{NH}_{4}\right)_{2} \mathrm{SO}_{4}$, resolution of the precipitate in water, precipitation by adjusting to $\mathrm{pH} 3.5$ and re-solution in water by adjusting to $\mathrm{pH} 7$. This procedure was repeated and the final volume of the resulting solution was made up to half that of the original TMV + antiserum mixture. The solution precipitated up to a dilution of $1 / 64$ with antiserum I (used at $1 / 200$ ), but it did not precipitate with antiserum II. 
Lesions were not produced on leaves of Nicotiana glutinosa after inoculation with the solution (undiluted and diluted 1/10 and 1/100).

The results of the absorption experiment showed that the virus preparation contained at least two serologically different materials: the characteristic virus particles and a small amount of some material with particles too small to be observed with the electron microscope, and which were non-infective. Antiserum I contained antibodies to both materials, whereas antiserum II contained antibodies to the typical virus particles only. The line $a$ in Figs. 1 and 2 was formed by the virus and the lines $b$ and $c$ by the other material. As this material formed two lines, presumably it contained at least two serologically different components.

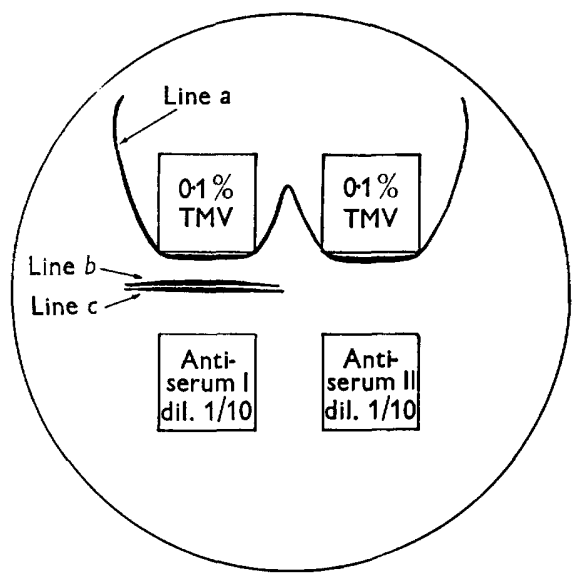

Fig. 2. A comparison of two different antisera to TMV.

\section{Separation of antigens by ultracentrifugation}

If the lines $b$ and $c$ of Figs. 1 and 2 are indeed formed by antigenic materials with relatively small particles, it should be possible to separate these materials from the virus by ultracentrifugation and thus obtain a serologically homogeneous virus preparation. Yet sedimentation from $1 \%$ solutions of TMV in water, or in $0.9 \% \mathrm{NaCl}$, at $\mathrm{pH}$ values round 7 gave no such separation. The redissolved pellet, obtained after two successive sedimentations at $\mathbf{4 0 , 0 0 0}$ $\mathrm{rev} . / \mathrm{min} .(80,000 \mathrm{~g})$ for $30 \mathrm{~min}$., behaved in the gel diffusion precipitin tests in exactly the same manner as the original virus preparation and the supernatant fluid produced no lines. By contrast with TMV, serologically homogeneous preparations of BSV were immediately obtained by two successive sedimentations by high-speed centrifugation, under the same conditions.

The preparation of 'TMV in $\mathrm{M} / 15$ phosphate buffer $(\mathrm{pH} \mathrm{7)}$ appeared electrophoretically homogeneous when examined in a Perkin-Elmer electrophoresis apparatus, even when the virus concentration was as high as $2 \%$. However, when tested in $0 \cdot 2 \mathrm{M}$-borate buffer ( $\mathrm{pH} 8 \cdot 7$ ), the preparation appeared to contain two other components besides the virus. The mobility of one was slightly smaller than half that of the virus, and that of the other only slightly less than that of the virus. The two components still formed the two electrophoretic 
peaks different from that of the virus, after the $\mathrm{pH}$ value had been brought back to 7 by dialysis first against water and then against $\mathrm{m} / \mathbf{1 5}$ phosphate buffer ( $\mathrm{pH} 7$ ). The mobilities of the two components exactly corresponded to those found by Jeener et al. (1954) for components of $X$-protein. Judging from the areas under the electrophoretic peaks, the total content of the two components of the virus preparation would be about $2-5 \%$ of the total protein. It looks, therefore, as if some materials that were combined with the virus at $c . \mathrm{pH} \mathrm{7,}$ split from the virus in the borate buffer at $\mathrm{pH} 8.7$ and did not recombine when the $\mathrm{pH}$ value was brought back to 7 . It seemed possible that these materials are the same as those which gave the lines $b$ and $c$ in the gel diffusion precipitin tests; therefore another attempt was made to separate the components of the virus preparation by high-speed centrifugation. This time $1 \%(\mathrm{w} / \mathrm{v})$ virus solution in borate buffer ( $\mathrm{pH} 8 \cdot 7$ ) was kept overnight at $2^{\circ}$ and then centrifuged for $30 \mathrm{~min}$. at $40,000 \mathrm{rev} . / \mathrm{min}$. $(80,000 \mathrm{~g})$. This did result in a separation. The pellet (which was dissolved in the original volume of water and the $\mathrm{pH}$ value adjusted to 7) appeared serologically homogeneous, forming only the line $a$ in the gel diffusion tests, whereas the supernatant fluid (which was dialysed against $0.9 \% \mathrm{NaCl}$, when the $\mathrm{pH}$ value fell to about 7 ) formed only the lines $b$ and $c$.

The infectivity of the material in the pellet, measured by the local lesion method on Nicotiana glutinosa, was about equal to that of TMV which had not been incubated at pH 8.7. The material that formed the line $a$ will, therefore, be called 'virus', and the symbol TMV will be used for standard virus preparations. The material contained in the supernatant fluid was non-infective (no lesions when $N$. glutinosa was inoculated at $300 \mathrm{mg}$./1.). The ultraviolet absorption spectrum had a maximum at $c .275 \mathrm{~m} \mu$. and a minimum at $255 \mathrm{~m} \mu$. Thus, if the material contained any nucleic acid at all, it was much less than in TMV. Electron-microscopic examination of the material after precipitation by 0.4 saturation with $\left(\mathrm{NH}_{4}\right)_{2} \mathrm{SO}_{4}$ and re-solution, showed rods similar to those of TMV and also numerous disks with holes near the centre, similar to those found by Schramm \& Zillig (1955) in partially aggregated preparations of $A$-protein. The material resembles, therefore, both $A$ - and $X$-proteins in its ability to aggregate into large rod-shaped particles.

The fact that the material could not be separated from the virus by ultracentrifugation or by electrophoresis before the preparation had been incubated in borate buffer at $\mathrm{pH} 8 \cdot 7$, seems incompatible with the fact that the material formed precipitation lines $b$ and $c$, separate from the line $a$ formed by the virus,

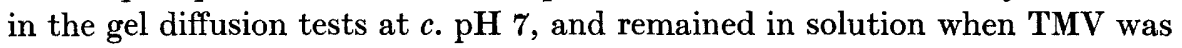
precipitated by a suitable antiserum, also at $c . \mathrm{pH} 7$. This apparent anomaly might be explained by assuming that when the virus is adsorbed to a colloid such as agar gel or serum protein, some of the material, which forms the lines $b$ and $c$, is dislocated from the virus particles. To test the assumption, a solution containing $1 \%(\mathrm{w} / \mathrm{v})$ of TMV and $1 \%$ of rabbit serum albumin at $\mathrm{pH} 7$, was centrifuged for $30 \mathrm{~min}$. at $80,000 \mathrm{~g}$, and the gel diffusion precipitin test set up with the pellet (redissolved in the original volume of water) and with the supernatant fluid. The pellet formed the lines $a, b$ and $c$, whereas the super- 
natant fluid formed only the lines $b$ and $c$. Thus some of the material which formed these lines did separate from the virus in the presence of $1 \%$ serum albumin.

\section{Comparison with $\mathbf{A}$ - and $\mathbf{X}$-proteins}

As various points of similarity between the material which gives $b$ and $c$ lines in the gel diffusion precipitin tests, and the $A$ - and $X$-proteins were noticed, it seemed possible that the material might be identical with one of them or with both, if indeed they are identical as suggested by Schramm \& Zillig (1955) and by Starlinger (1955). To test this, $A$ - and $X$-proteins were prepared, and each was compared with a standard preparation of TMV by the gel diffusion precipitin test.

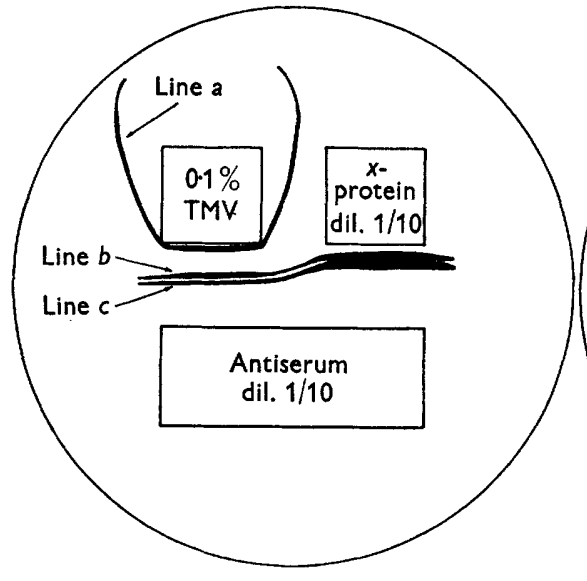

Fig. 3. A comparison of $\boldsymbol{X}$-protein with a TMV preparation.

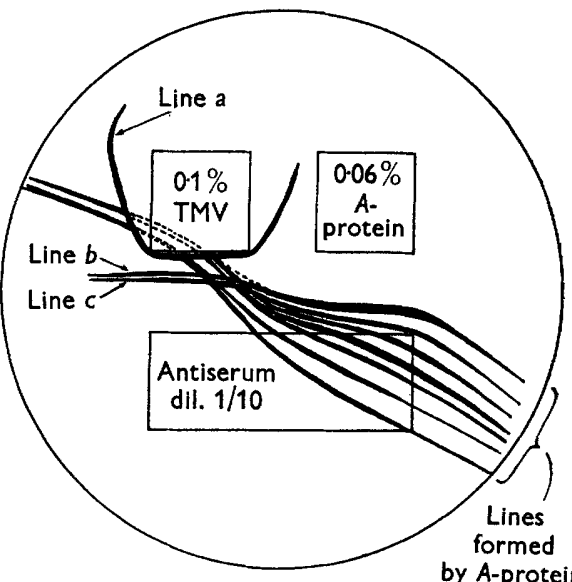

Fig. 4. A comparison of $A$-protein with a TMV preparation.

$X$-protein was prepared by removing TMV from fresh sap of infected tobacco plants by high-speed centrifugation and concentrating the $X$-protein by precipitation from the supernatant fluid by $0 \cdot 4$ saturation with $\left(\mathrm{NH}_{4}\right)_{2} \mathrm{SO}_{4}$ and re-solution in a volume of water equal to one-tenth the original volume of sap. The fluid was dialysed against water and clarified by removing insoluble material by low-speed centrifugation $(6000 \mathrm{~g})$.

Figure 3 shows the result of a comparison of $X$-protein with the standard preparation of TMV when both were tested on the same agar plate against the antiserum to TMV. The TMV preparation formed its usual three precipitation lines $(a, b$ and $c)$, whereas $X$-protein formed two rather ill-defined lines which deviated from their course to fuse with the lines $b$ and $c$ of the TMV preparation and to form their continuations. $X$-protein did not form any line which corresponded to the line $a$ of the TMV preparation. Thus $X$-protein seems to be antigenically identical with the material or materials which formed the lines $b$ and $c$, and does not seem to contain anything identical with the material which formed line $a$.

$A$-protein was prepared from the virus which was previously separated by 
ultracentrifugation at $\mathrm{pH} 8.7$ from the material that formed the lines $b$ and $c$. A $1 \%$ solution of the virus was adjusted to $\mathrm{pH} 10 \cdot 2$ with $0 \cdot 1 \mathrm{~N}-\mathrm{NaOH}$ and kept for $24 \mathrm{hr}$. at $2^{\circ}$. The solution was then dialysed against $\mathrm{x} / 15$ phosphate (pH 7) for $24 \mathrm{hr}$. at $2^{\circ}$ and examined in the electrophoresis apparatus. Three peaks were observed, similar to those obtained by Schramm et al. (1955): one small peak with a mobility about 1.7 times that of TMV, another large peak corresponding to unchanged TMV, and a third large peak corresponding to $A$-protein, with a mobility just less than half of that of TMV. The area under the third ( $A$-protein) peak was about half of that under the second (TMV) peak.

Some of the component which formed the third peak ( $A$-protein) was removed from the electrophoresis cell without the other components. The preparation of $A$-protein thus obtained gave a UV absorption spectrum with a maximum between 275 and $280 \mathrm{~m} \mu$. and a minimum at about $252 \mathrm{~m} \mu$. Thus, if this protein contained nucleic acid at all, it was much less than in TMV. The preparation produced only a few lesions per half-leaf of Nicotiana glutinosa when inoculated at a concentration of $300 \mathrm{mg}$./l., in contrast to many on the opposite halves of the leaves inoculated with TMV at $5 \mathrm{mg} . / \mathrm{l}$. The few lesions probably occurred because the $\boldsymbol{A}$-protein was contaminated with infective virus in the electrophoretic cell. On the other hand, infectivity of the virus which

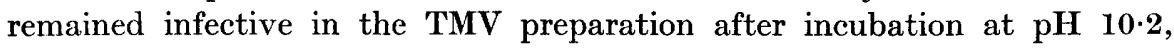
appeared even greater than that of the original virus preparation. The increased infectivity of virus particles which remained infective after exposure to alkali made impossible any estimation of the proportion of particles whose infectivity was destroyed by this exposure.

Figure 4 compares $A$-protein with the standard preparation of TMV when both were tested on the same agar plate against the antiserum to TMV. The TMV preparation again formed the usual three precipitation lines $(a, b$ and $c)$, whereas the $A$-protein formed at least seven lines. On the left of the original position of $\boldsymbol{A}$-protein the lines were so close to each other that most of them merged, but they fanned out and became separate farther to the right, i.e. towards the space between the original positions of $\boldsymbol{A}$-protein and of antiserum, and most of the lines passed across the area of the original position of the antiserum. The lines which were the farthest from the antigen area first formed much nearer to that area than shown in Fig. 4, and then moved farther away across the antiserum area.

The course of the lines formed by $A$-protein was altered by the presence of the TMV preparation. The course they would have taken had the TMV preparation not been there, is shown by broken lines (this is copied from a plate identical to that shown in Fig. 4 except that it did not contain the TMV preparation). The lines $b$ and $c$ crossed several lines formed by $A$-protein, to fuse with two of them which were nearest to the antigen area. These lines deviated from their course to cross the other lines and form continuations of lines $b$ and $c$. It is concluded, therefore, that $A$-protein contains two antigenically different components, one of which is antigenically identical with the material forming the lines $b$ and $c$, and thus antigenically identical with 
$X$-protein. The multiplicity of lines formed by the two components suggests that each was a mixture of antigenically different materials.

The lines that were formed by $A$-protein which did not deviate to fuse with the lines $b$ and $c$ continued their independent course until they encountered line $a$. They did not continue beyond line $a$, but they appeared to the left of the line $a$ after it turned sharply upwards (i.e. away from the antiserum area). In other words, no line could be formed by $A$-protein at any point which lay on the side of the $a$ line opposite to that of the antiserum. It seems, therefore, that none of the antibodies which could precipitate components of $\boldsymbol{A}$-protein, could pass unhampered through the line $a$. As the line $a$ was formed by the typical virus particles, and as antibodies can diffuse freely through precipitates formed in agar by unrelated antigen-antibody systems (Wilson \& Pringle, 1955), the conclusion reached is that the antiserum did not contain any antibodies specific for $\boldsymbol{A}$-protein which were not also specific for typical virus particles.

\section{DISCUSSION}

There is no conclusive evidence that the proteins which can be separated from purified preparations of TMV, and which are antigenically identical with $X$-protein, are identical with $X$-protein in all respects. $X$-protein is found in sap of infected tobacco plants and can be separated from virus by high-speed centrifugation. It might be concluded that $X$-protein and the virus existed in the sap separately, i.e. were not combined with each other. However, the protein which is antigenically identical with $X$-protein, seems to be combined with the virus with different degrees of firmness. Some can be detached by such mild treatment as placing in a protein solution or in agar gel, more can be split off by a somewhat more drastic treatment, such as placing in borate buffer at $\mathrm{pH} 8.7$. Still more can be released by a still more drastic treatment, such as exposure to alkali at $c . \mathrm{pH} 10$, but then some of the virus particles disintegrate, and another kind of protein, different antigenically from $X$-protein, is also released. There is even no conclusive evidence that all the successive yields of protein antigenically identical with $X$-protein, are identical in all respects among themselves. Since, however, they share with $X$-protein a number of other common features (e.g. electrophoretic mobility, particle size, ability to aggregate into particles resembling those of the virus) it seems very probable that they are identical with $X$-protein. If this be assumed, the material which is released from the virus at $\mathrm{pH} 10$, consists of $X$-protein and of another antigenically different protein which it is proposed to designate as $Y$-protein. The protein designated by Schramm et al. (1955) as $A$-protein is not, therefore, identical with $X$-protein, but is a mixture of $X$ - and $Y$-proteins.

Both $X$-protein and $Y$-protein seem to consist of mixtures of antigenically different materials. $X$-protein formed two precipitation lines with one of the antisera to TMV, and $\boldsymbol{Y}$-protein formed at least five other lines. Multiplicity of lines cannot alone be considered as sufficient evidence for a corresponding multiplicity of antigenically different components, but there is corroborative evidence for this with $X$-protein, namely that some antisera formed only one 
line with it. If the two lines were not a result of the presence of two different antigens, and if some sort of mechanism operated whereby an antigenically homogeneous material produced multiple lines (as discussed in Methods), the multiple lines would be expected with all antisera of comparable strength. It can be assumed, therefore, that there are at least two antigenically different components in $X$-protein. Antisera which formed only one line did not necessarily lack antibody to one of these components, but may have contained different kinds of antibodies in such a ratio that the two lines coincided, for positions of lines depend on the relative concentrations of antigens and antibodies at the initial positions. $\boldsymbol{Y}$-protein probably consists of at least five antigenically different components, but there is no corroborative evidence for this. It seems, therefore, that the protein units of molecular weight of about 90,000 into which, according to Schramm \& Zillig (1955), TMV is disintegrated by alkali treatment, or those of molecular weight of about 20,000 which according to an X-ray study by Franklin \& Holmes (1956) are arranged helically along the virus particle, are not all identical, but are of several kinds, differing from each other antigenically.

It does not seem likely that the presence of free $X$-protein in the sap of infected plants is a result of disintegration of the virus, because then one would expect free $\boldsymbol{Y}$-protein also to be present. The possibility that free $\boldsymbol{X}$ protein is a precursor of the virus is also made less likely by the absence of free $Y$-protein. As some $X$-protein is easily detached from the virus, it is quite possible that free $X$-protein was originally attached to the virus, although it is also possible that it was originally free and subsequently got loosely adsorbed to the virus.

I thank Mr H. L. Nixon for making electron micrographs and Mr N. W. Pirie, F.R.S., for doing ultracentrifugations.

\section{REFERENCES}

Bawden, F. C. \& Pirie, N. W. (1956). Observations on the anomalous proteins occurring in extracts from plants infected with strains of tobacco mosaic virus. J. gen. Microbiol. 14, 460.

Commoner, B. \& Rodenberg, S. D. (1955). Relationships between tobacco mosaic virus and the non-virus proteins. J. gen. Physiol. 38, 475.

Commoner, B., Yamada, M., Rodenberg, S. D., Wang, T. \& Basler, E. (1953). The proteins synthesized in tissue infected with tobacco mosaic virus. Science, $118,529$.

Franklin, R. E. \& Holmes, K. C. (1956). The helical arrangement of the protein subunits in tobacco mosaic virus. Biochim. biophys. Acta, 21, 405.

Jeener, R., Lemoine, P. \& Lavand'Homme, C. (1954). Détection et propriétés de formes du virus de la mosaïque du tabac dépourvue d'acide ribonucléique et non infectieuses. Biochim. biophys. Acta, 14, 321.

OAkrey, C. L. \& Fulthorpe, A. J. (1953). Antigenic analysis by diffusion. J. Path. Bact. 65, 49.

Ouchterlony, O. (1949). Antigen-antibody reactions in gels. Ark. Kemi Min. Geol. 26B, no. 14.

SANG, J. H. \& Sobey, W. R. (1954). The genetic control of response to antigenic stimuli. J. Immunol. 72, 52. 
Schramm, G. (1943). Über die Spaltung des Tabakmosaikvirus in niedermolekulare Proteine und die Rückbildung hochmolekularen Proteins aus den Spaltstücken. Naturwissenschaften, 31, 94.

Schramm, G., Schumacher, G. \& Zillig, W. (1955). Über die Struktur des Tabakmosaikvirus. III. Mitt.: Der Zerfall in alkalischer Lösung. Z. Naturf. 10 b 481 .

Schramm, G. \& Zillig, W. (1955). Über die Struktur des Tabakmosaikvirus. IV. Mitt.; Die Reaggregation des nucleinsäurefreien Proteins. Z. Naturf. 10 b, 493.

Slogteren, D. H. M. van (1955). Gel diffusion of tobacco mosaic virus, demonstrated by serological analysis of its components and by electron-microscopy. Acta bot. Neerl. 4, 472.

Starlinger, P. (1955). Vergleich der serologischen Spezifität des Tabakmosaikvirus mit nucleinsäure-freien und -haltigen Abbauprodukten des Virus. Z. Naturf. $10 b, 339$.

TAKAHASHI, W. N. \& Ishit, M. (1952). An abnormal protein associated with tobacco mosaic virus infection. Nature, Lond. 169, 419.

Takahashi, W. N. \& Ishit, M. (1953). A macromolecular protein associated with tobacco mosaic virus infection: its isolation and properties. Amer. J. Bot. 40, 85.

Wilson, M. W. \& Pringle, B. H. (1954). Experimental studies of the agar-plate precipitin test of Ouchterlony. J. Immunol. 73, 232.

Wilson, M. W. \& Pringle, B. H. (1955). Interpretation of the Ouchterlony precipitin test. J. Immunol. 75, 460.

(Received 28 September 1956) 